\title{
FROM THE ROOTS TO THE PRESENT OF PERSONAL FINANCIAL PLANNING - ACHIEVEMENTS ON THE 50TH ANNIVERSARY OF THE MOVEMENT
}

\section{Krzysztof Waliszewski ${ }^{*}$ H. Oliver Welch ${ }^{* *}$}

\begin{abstract}
The purpose of the article The aim of the article is to present the reasons for the emergence of personal and financial planning in the 1960s in the US, and then its quantitative and qualitative evolution around the world, taking into account institutional aspects.

Methodology Review of the literature on the subject, legal acts and statistics of the financial advisory movement.

Results of the research The study found that personal financial planning emerged from a grassroots initiative as a response to the needs of consumers and progressive representatives of the financial sector. Its territorial expansion beyond its homeland was associated with a growing awareness of the benefits of financial advisory services to households. Before the entire financial planning movement there is enormous growth potential.
\end{abstract}

Keywords: personal financial planning, financial advisors, personal finance, consumer protection.

JEL Class: G23, G5, G1.

The author would like to thank Ben G. Baldwin, Harold Evensky, A. William Gustafson, Noel Maye, Edwin P. Morrow II, Page Lambert Dunton

for assistance offered while writing the article

\footnotetext{
*Associate Professor, Institute of Finance, Poznan Univeristy of Economics; https://orcid.org/0000-0003-4239-5875.

${ }^{* *}$ Doctor, Chairman emeritus of the Certified Financial Planner Board of Standards.
} 


\section{INTRODUCTION}

In 2019, personal finance planning and the financial planner profession celebrated their 50th anniversary. The main impetus behind the establishment of personal financial planning was when a group of stock brokers, mutual fund salesmen, and life insurance salesmen realized that they could serve the consumers better by giving their clients an in-depth interview and use all products at their disposal instead of just selling one. In addition, factors related to the growing interest in retirement security and legal regulations cannot be overlooked. Since its establishment, a gradual expansion of education and CFP certification has been observed, initially in the United States - the homeland of the profession - and then since 1990 outside the United States on a global scale throughout all continents. According to data from the end of 2019, CFP advisors were operating globally in 26 countries. This is a good time to take stock of the achievements and challenges for the financial planning profession. The future will be affected by macroeconomic, regulatory, technological, socio-cultural factors as well as the level of knowledge and financial intelligence in societies. The purpose of the article is to analyse the conditions that led to the emergence of the profession of financial adviser, the characteristics of its development over the last half century, as well as an attempt to determine directions for future development.

\section{ROOTS OF PERSONAL FINANCIAL PLANNING}

The beginnings of personal financial planning date back to 1933, when the Securities Act of 1933 was passed, with the aim of protecting investors from a repeat of the 1929 stock market crash. Then the Investment Advisers Act of 1940 established guidelines for regulating the investment industry. In spring 1963, the Financial Services Corporation [founded in 1958 in Atlanta] - an independent broker/dealer operating in insurance founded by John Keeble and Richard Felder - created their first comprehensive, needs-based financial plan, and went on to produce about 300 plans a month by 1968 (Cato, 2002a). In 1966 a special department of personal plans was created in Financial Services Corporation and John Keeble first recognized that customer needs drive sales in personal financial planning in terms of products such as insurance and investments (Morrow, 2002a). The personal financial planning process invented by John Keeble (2003) was divided into four parts:

- interview,

- data collection,

- analysis and plan development,

- implementation with products and services. 
Many financial advisors visited John in Atlanta to learn how develop these plans. John Keeble invited Loren Dunton ${ }^{1}$ [photo 1 and 2] - a popular motivational speaker for the life insurance industry at a time when life insurance agents were finally being allowed to sell different financial services (Cato, 2002a). In 1964, he sold everything but the kitchen sink, and took his wife Jane and 2 daughters Page and Brooke - on a yearlong trip around the world. During a sabbatical spent visiting 27 countries with his first wife Jane and 2 daughters during 1964-1965, Dunton was asked about the prosperity of the U.S., and why Americans were so dependent on a government bureaucratic Social Security for the retirement of their population. Loren was forced to admit that Americans did not plan for their retirement. From this, he concluded that what was needed was a new profession one dedicated to personal financial advice and services (Morrow, 2002b).

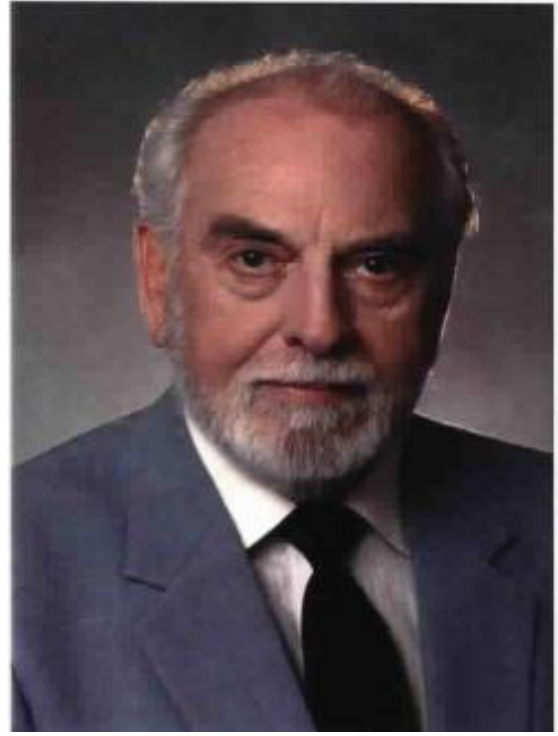

Photo 1. Loren Dunton [1918-1997]father of personal financial planning

Source: Institute of Consumer Financial Education.

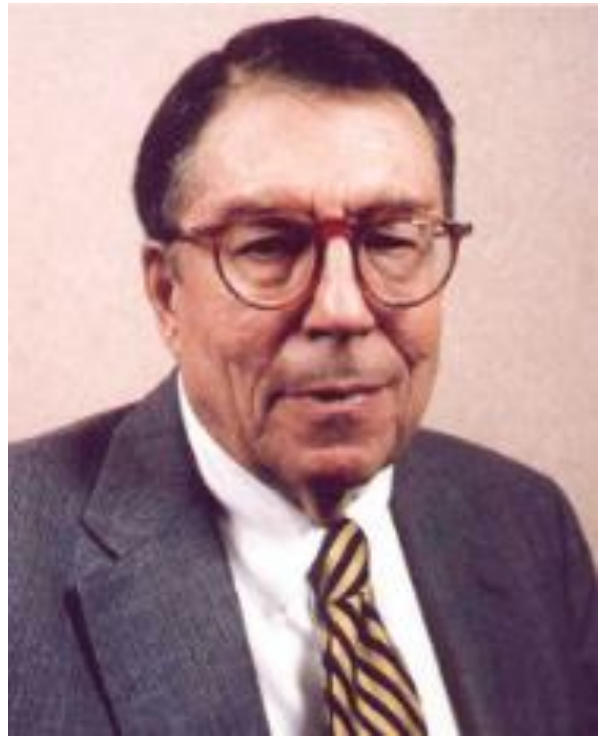

Photo 2. John III Keeble [1929-2004]pioneer in writing and implementing personal financial plans

Source: IARFC.

${ }^{1}$ Loren Dunton never sold a financial product. What he did do was train others on the process of professional sales techniques. Loren Dunton was never a financial planner, but he had an early vision of what we could be according to his quote: 'I'm the only guy who created profession he never practiced' source: Moreau, Dan, CHANGE AGENTS: Loren Dunton put financial planning on the map, but he cares little about making, Changing Times; May 1990. 
After one of Loren's speeches to John's group, John told Loren that he wanted to move from the current sales platform for client engagement to an advice platform and Loren was hooked and all the documentation that he had brought to the 1969 meeting would further the concept of client engagement via an advice platform and provide structure and credibility to what John's salespeople were already doing. Loren Dunton decided to implement the vision by creating specialized institutions for the education and training of future financial advisors and their association. While Loren Dunton has been credited as the founder of financial planning institutions and the godfather of the profession, personal financial planner John III Keeble is considered as a pioneer in writing and implementing personal financial plans and a financial planning visionary ${ }^{2}$.

On 19 June 1969 the Society for Financial Counselling Ethics [SFCE] was founded by Loren Dunton in Colorado as a nonprofit 501[c][3] Corporation. The society's charter identified two purposes for the organization:

- To give recognition to those who meet not only the legal but also the ethical standards of financial counselling and conscientiously share their wealth of knowledge with the public.

- To establish an educational institute providing a certification program outside of either the mutual fund or insurance industry, and to provide objective guidance and assistance to the public in the form of financial advice.

Financial planning was officially born on 12 December 1969, Saturday morning at 10 am in a second floor hotel meeting room near Chicago's O'Hare Airport. Although the gathering's organizers, Loren Dunton and James R. Johnston, had contacted everyone they knew in financial services, only 11 men showed up, paying their own expenses to travel from Florida, New York, Ohio, and Pennsylvania. Twenty-two people failed to show-up as promised.

${ }^{2}$ Loren Dunton, the man most credited as the father of financial planning, often labeled Keeble, The real father of financial planning!' Dunton is called, 'The man who invented a profession that he never practiced.' Loren once said that 'John Keeble not only practiced financial planning, but John Keeble created and perfected the practice that everyone uses today from coast to coast.' See: Cato (2002b). 


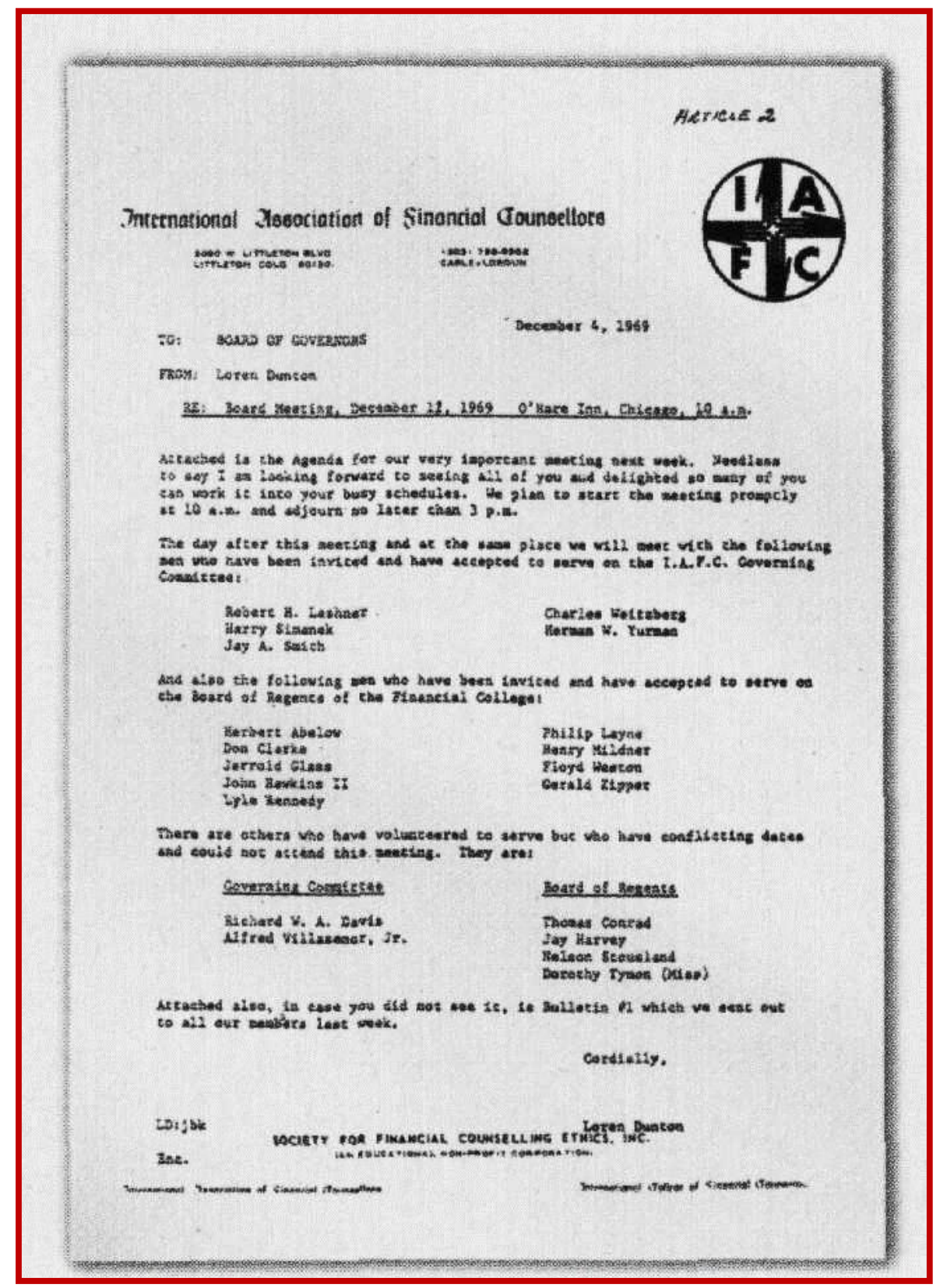

Photo 3. Meeting invitation December 12, 1969

Source: Baldwin, 2000. 
The 13 men who attended the two-day December 1969 planning session now called the Chicago 13 were (Brendon and Welch, 2009):

1) Herbert Abelow: Queens County, New York. Vice president of sales for one of Dreyfus's largest offices, a respected name in the mutual fund industry.

2) Loren Dunton: Littleton, Colorado. Meeting organizer; founder of the Society for Financial Counselling Ethics; organizer of the December 1969 planning session.

3) Walter Fischer: Million-dollar mutual-fund salesman for Baxter, Blydern, Selheimer \& Co.; vice president of the Mutual Funds Council.

4) Jerrold Glass: St. Petersburg, Florida. Regional vice president of Supervised Investors Services. Served on the first education committee [19701972] and on the College for Financial Planning's first board of regents.

5) John Hawkins: Pompano Beach, Florida. Owner of John Hawkins \& Co., Inc., a securities firm. Served on the IAFC's original board.

6) James R. Johnston: Denver, Colorado. Co-organizer of planning session; became College for Financial Planning's first employee.

7) Lewis G. Kearns: Philadelphia. Director of financial planning, Wellington Management Company, which managed the $\$ 1.5$ billion Wellington Fund. Chaired the planning session; served as interim chair of the education committee; served two years as College for Financial Planning's first board of regents chairman and later returned for a third term.

8) Lyle Kennedy: New York City. Principal in a broker membership.

9) Robert Leshner: Cincinnati. Salesman for W.D. Gradison \& Co.; early promoter of IAFC sales workshops and memberships.

10) Hank Mildner: Pompano Beach, Florida. Veteran mutual fund salesman for Consolidated Securities.

11) Charles Weitzberg: A friend of Loren Dunton's.

12) Herman W. [Hy] Yurman: St. Petersburg, Florida. Vice president of Planning Corporation of America, a life insurance subsidiary of Raymond James and Associates. Served on first education committee; assisted in writing CFP curriculum.

13) Gerald Zipper: New York. Publicist, publisher of a financial newsletter.

Those founders, who were mostly from the mutual fund and insurance sectors, set out to develop a new way of providing financial guidance. Instead of focusing on the sale of financial products, they would concentrate on helping clients manage their finances. It would not just be about portfolios. It would be a holistic, integrated and client-centred approach (Schoeff, 2019a). These industry leaders, primarily from the insurance and mutual fund industry, recognized that consumers would be better served by working with professionals who followed a standardized code of ethics and practice standards (Grabe et al., 2011). At that time, financial services were largely categorized; securities and stock brokerage 
in one, insurance in another, banking in another (Walker, 2018). Dunton claims the climate back in the late 1970's and early 1980's drove the need for financial planning. He correctly observed that most of the players in investments were only looking out for their own best interests. They were not considering the best financial plan for the customer. Banks thought deposit accounts were the answer to everything. Insurance salesmen said insurance was the only answer. Stockbrokers focused on moving the customer's pile of money over to their own personal pile by excessively trading anything just to earn commissions. Consumer goods companies advertised and pushed spending versus saving. Mutual fund companies ignored insurance. Real estate brokers said forgot stocks, mutual funds, and insurance because real estate was the answer. Dunton also correctly observed that the American school system did a lousy job of educating their citizens about saving and investing. Some believed that personal financial planning was totally separate from selling insurance and investment products. Loren Dunton always recognized that they were different taproots of the same tree (Morrow, 2000) and that products are necessary elements in the implementation of a financial plan. He saw a financial planner as a family doctor - a general practitioner dedicated to the poor and the middle class.

Dunton called that gathering the 'Preliminary National Committee and Financial College Organization' and the event created new organizations and a new profession, all founded by Dunton. During the December meeting, a decision was made to create and fund the concept of a college for educating a new type of professional - a financial planner - along with a name proposed by Herman W. [Hy] Yurman, a Certified Financial Counselor [CFC]. Institutions formed under the Society for Financial Counselling Ethics umbrella were:

1) International Association of Financial Counselors [IAFC] in Denver, Co as a membership organization, renamed the International Association of Financial Planners [IAFP], created as the result of Loren traveling from city to city speaking with financial services professionals and mutual funds companies encouraging them to formulate individual chapters of the IAFP,

2) International College for Financial Counseling [ICFC] in Denver, Co as an education facility, renamed the College for Financial Planning [CFP] in mid-1970.

In 1970 Loren Dunton found himself in front of the chairman of the Securities and Exchange Commission advocating a new profession he created for graduates of the College, to be known as a 'Certified Financial Planner [CFP]'. In the process of research before registering the trademark, the SEC objected to Certified Financial Counselor so he inquired about CFP and since there was no objection to CFP, the rest is history. In 1971 a five-course curriculum leading for CFP designation was created by James Johnston and Lew Kearns consisting of (Dunton, 1986): 
1) Basic Financial Planning.

2) Investments.

3) Risk Management.

4) Professionally Managed Investments.

5) Counselling in Business.

In 1971 Loren Dunton's Society for Financial Counseling founded and published The FINANCIAL PLANNER Magazine to help publicize planning concepts. Lewis B. Kearns created the syllabus for the College for Financial Planning (Ritchlin, 2009a). Kearns looked to the Chartered Financial Analyst [CFA] program, which with its training, certification, and requirement for periodic renewal, seemed a better model for the new financial planning credential he envisioned (Ritchlin, 2009b). In 1972, an initial CFP exam consisting of 150 essay questions was prepared by the College for Financial Planning's volunteer education committee. As the profession began to coalesce, John Keeble took a leading role. He served on the board of the Society of Financial Counseling, the predecessor to the IAFP, and was the keynote speaker at the first meeting of the IAFP in 1972 in Hollywood, Fla. Since then, he has been a regular attendee and participant at industry meetings. He shared his experiences at the FPA broker/dealer conference and the NAIFA Financial Advisors Forum in Philadelphia (Morrow, 2002a).

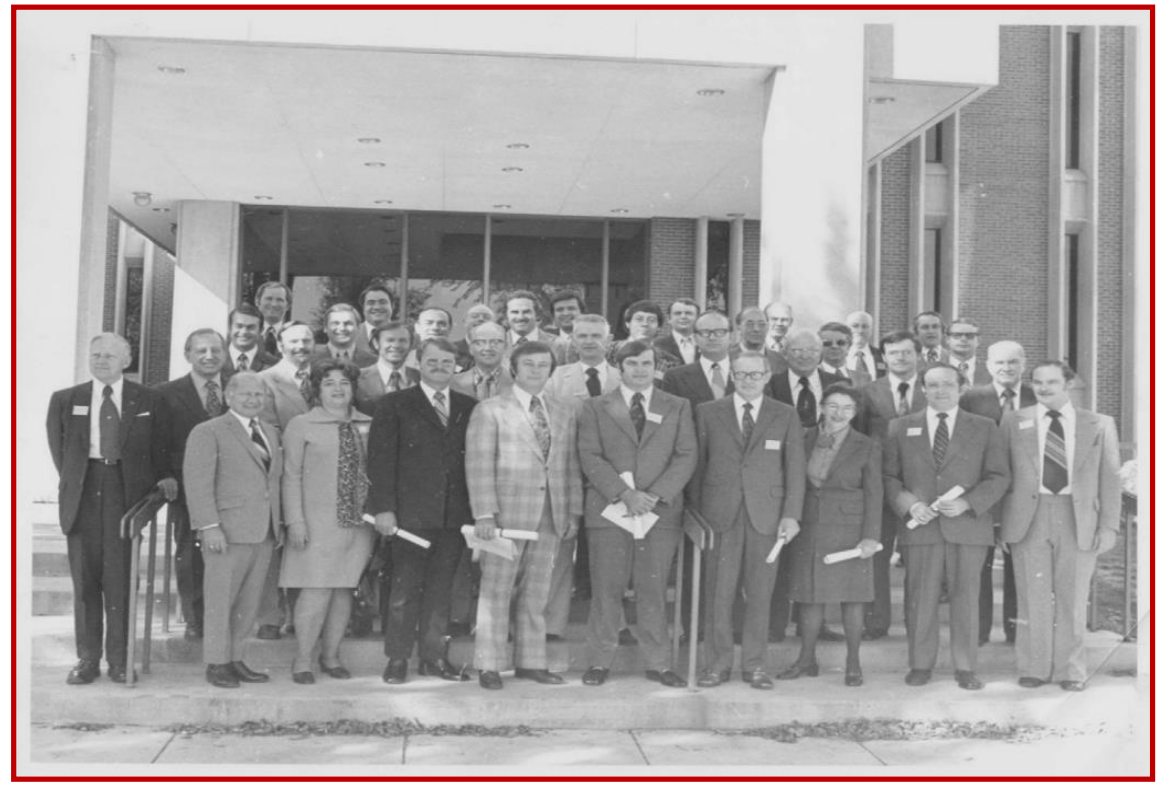

Photo 4. First graduating class, College for Financial Planning, 1973

Source: Financial Planning Association. 
In 1973 the first CFP professionals appeared on the world stage, when 42 individuals graduated from the College for Financial Planning in Denver [photo 4]. Thirty-six of the first class of CFP designees meet to form an alumni association, the Institute of Certified Financial Planners [ICFP]. In the same year, the IAFP formally split from the financially struggling Society for Financial Counseling and adopted an 'open forum' philosophy, in which members from all financial disciplines were welcome, whether they had qualified as CFPs or not. The ICFP was open only to CFP ${ }^{\circledR}$ practitioners. The IAFP was open to anyone in financial services. Many CFP ${ }^{\circledR}$ practitioners were members of both organizations.

One member of the first CFP class in 1973 was P. Kemp Fain, Jr., an advocate of 'one profession, one designation'. He was the primary author of the famous white paper in 1987 on unifying the profession and delivered a speech at the national meeting of financial planners in 1988. Kemp envisioned the CFP ${ }^{\circledR}$ designation as the one trademark that would represent professionalism in financial planning, similarly to how CPA is respected in accounting. In 1993, the ICFP established the P. Kemp Fain Jr. award. Presented annually, this award is the pinnacle of recognition, honouring one exceptional individual who has made outstanding contributions to the financial planning profession. The award continues to be granted each year by the FPA [table 1] (Walker, 2018).

Table 1. P. Kemp Fain, Jr., Award
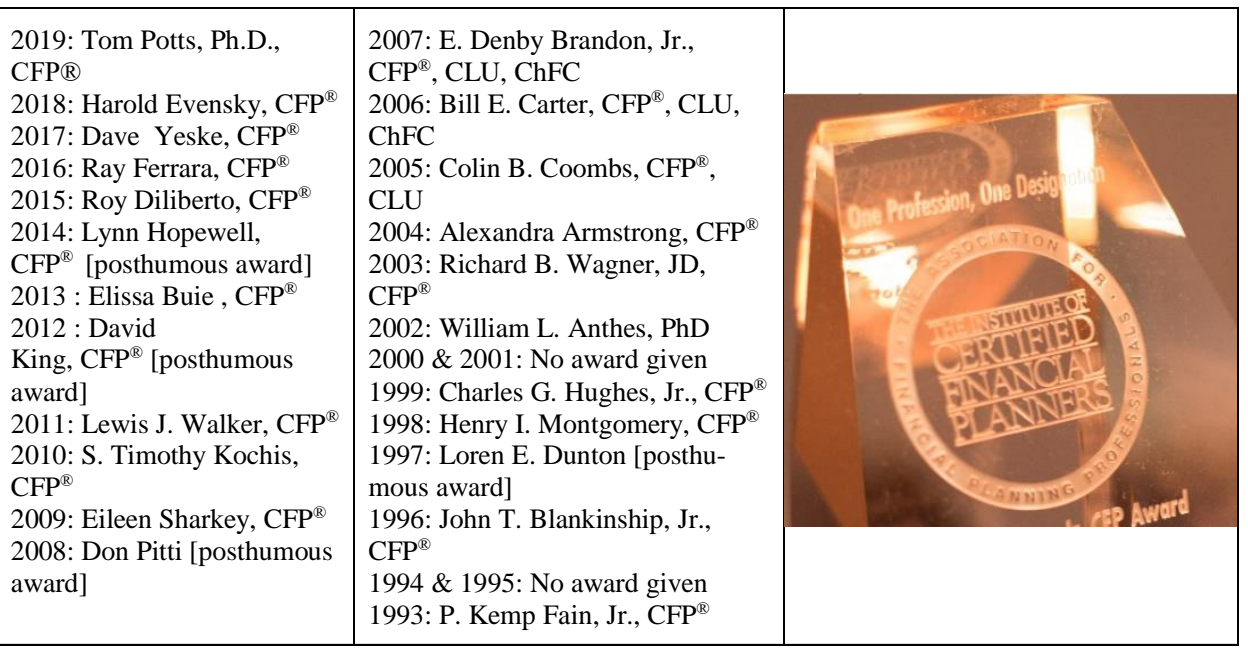

Source: FPA. 
The early years saw the tools of finance and economics translated from the corporate realm to that of the household. Financial statement analysis, tax planning, time-value-of money, portfolio optimization, and risk management techniques part of the traditional toolkit of corporate analysts and consultants were now reconceptualized to meet the needs of individuals and families (Yeske, 2019).

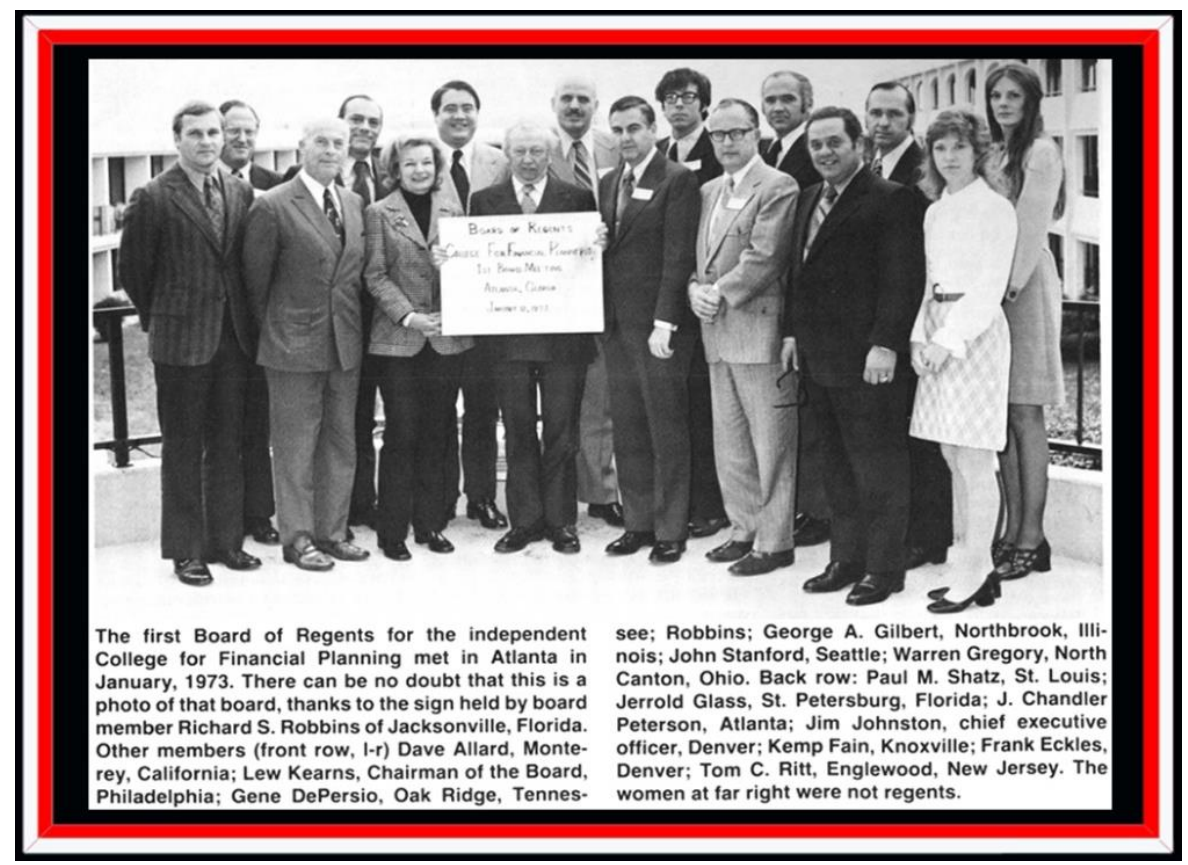

Photo 5. The first Board of Regents for the Independent College for Financial Planning (1973)

Source: Photo shared by A. William Bill Gustafson from Archives for the History of Financial Planning at Texas Tech University.

The profession's early leaders encountered countless obstacles: limited resources, personality conflicts, philosophical rifts, ethical misdeeds within the ranks, public and media misperceptions and resistance from financial services industry itself (Peck, 2009) for the first five years this struggling organization barely survived as there were never adequate operating funds. Dunton went deeply into debt to keep the effort functioning and was never repaid as often promised. These pioneers remained unable to attract sufficient support, received no government help, and many initial volunteers quickly departed. They reorganized three times, changes names, initiated and then terminated various projects, almost disbanded on four occasions, and always operated in the red. The first few years were rough for College, Association and Society. Because of finances the 
beginning time remained a constant plague (Origins of Our Profession, 2008). In 1975 Society for Financial Counseling dissolves without a firm financial base. By the end of 1972, just three years after its official birth, the financial planning movement had achieved remarkable results. The International Association of Financial Planners, its membership organization, had 3,000 members in 37 U.S. chapters and representation in 22 other countries. The College for Financial Planning had enrolled 137 students and had become an independent entity. Loren Dunton took the reins of the Society for Financial Counselling Ethics and the International Association of newly formed Financial Counselors, with Lewis Kearns and James R. Johnston focusing on the International College for Financial Counseling. But he proved to be more successful as a motivator than as an administrator, and both organizations struggled financially under his leadership. Dunton stepped down in 1974 and moved to San Francisco, where he wrote books, gave speeches, and founded several nonprofit groups, including the Institute for Consumer Financial Education [ICFE]. In 1987 the ICFE/NCFE was awarded a Presidential Citation for Private Sector Initiatives from President Reagan. Loren Dunton died of a cerebral haemorrhage in San Francisco in 1997 at age 79. His ashes were scattered in the Pacific Ocean.

\section{DEVELOPMENT AND TERRITORIAL EXPANSION OF PERSONAL FINANCIAL PLANNING}

In period 1974 to 1975 the US went into a recession, causing inflation which caused the markets to crash, not helping the financial planning business. In 1974, despite a mounting recession, membership gradually increased and more than 500 members of the IAFP congregated in San Francisco for the first convention. While the College, the IAFP and the new 'alumni' group [the ICFP] were still to encounter problems, they weathered the storms and flourished. In 1984 College for Financial Planning teams up with the Cooperative Extension Service of the U.S. Department of Agriculture to form the High School Financial Planning Program. In 1979 begun the Journal of the Institute of Certified Financial Planners [which in 1988 became the Journal of Financial Planning] published peer-reviewed articles for the academic and practitioner communities with original mission 'to inform its readers of innovative and constructive tools in financial planning' (Tuttle, 1996). In 1981 was founded International Foundation for Financial Planning [IAFP Foundation] to help with public awareness; renamed as Foundation for Financial Planning in 1995 with a new mission of connecting financial planners with people in need through pro bono and outreach activities. In 1982 Loren Dunton, reactivated Society for Financial Counselling and established the Institute of Consumer Financial Education [ICFE] as a 501c3, non-profit public education organization, headquartered in San Francisco, CA. In 1983 The National Association of 
Personal Financial Advisors [NAPFA] was created. NAPFA's mission and purpose was, from the beginning, to support and promote the delivery of fee-only financial planning advice. While always the smallest among financial planning groups by membership, NAPFA has nonetheless managed to wield an outsized influence in the public realm (Yeske, 2016).

Since 1983 IAFP promotes a six-step process for financial planners to follow when working with clients. For clients, these were the key steps:

1) Clarify your present situation by collecting and assessing all relevant personal and financial data.

2) Decide where you want to go by identifying financial and personal goals and objectives.

3) Identify financial problems that create barriers to achieving your goals.

The planner's role comprised three subsequent steps:

1) Provide a written financial plan that meets specific standards.

2) Implement or coordinate the implementation of the right strategy to ensure that the client reaches his or her goals and objectives.

3) Provide periodic review and revision of the plan to ensure that the client stays on track.

In 1984 International Association of Registered Financial Consultants, [IARFC ${ }^{\circledR}$ ] was founded by John Gargan as a non-profit professional Association formed to foster public confidence in the financial services profession, help financial consultants exchange planning techniques, and recognize practitioners who are truly committed to ethical standards and continuous professional education.

Table 2. Loren Dunton Memorial Award recipients

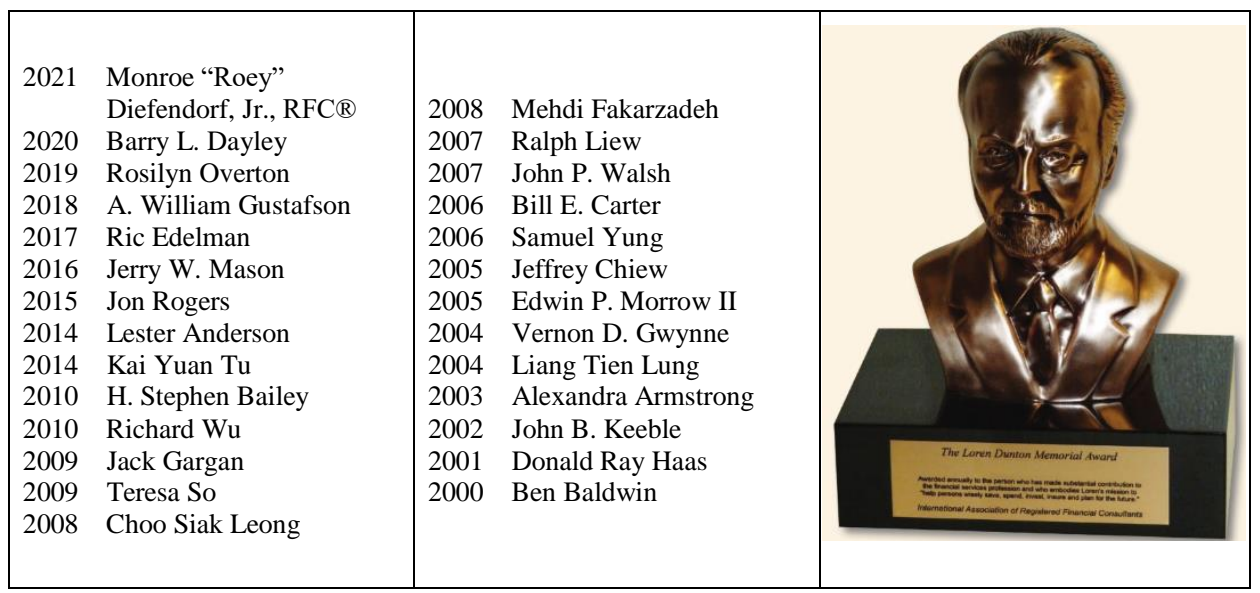

Source: IARFC. 
The IARFC Mission Statement is as follows: supporting advisors 'helping persons spend, save, invest, insure and plan for the future in order to achieve personal independence.' Since 2000 IARFC launched Loren Dunton Memorial Award, a bronze bust of Dunton on a marble base, preserves the memory of the founder of a profession presented to persons who have delivered significant service to the operation and growth of the International Association of Registered Financial Consultants [table 2]. The first winner of the Loren Dunton Memorial Award was Ben Baldwin, close friend of Loren and Marta Benko Dunton.

In 1984, the Financial Products Standards Board was funded by the ICFP as a public service and independent organization. Guidelines and standards were drafted for structuring real estate limited partnership investments, mutual-fund, and oil-and-gas industries.

In 1985, the College entered an agreement to establish an independent, nonprofit certifying and standards-setting organization, and transferred ownership of the $\mathrm{CFP} \AA$ trademark and responsibility for continuing the $\mathrm{CFP} \AA$ certification program to the new organization, the International Board of Standards and Practices for Certified Financial Planners, Inc. [IBCFP] based in Englewood, Colorado [photo 5]. The Certified Financial Planner Board of Standards, Inc. [CFP Board] was founded in 1985 as a 501[c][3] non-profit organization that serves the public interest by promoting the value of professional, competent and ethical financial planning services, as represented by those who have attained CFP®

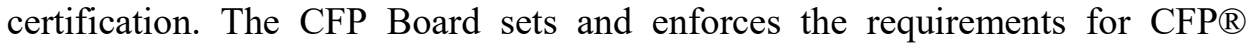
certification, including 4E: Education, Examination, Experience, Ethics. Individuals who successfully complete the CFP Board's initial and ongoing certification requirements are authorized to use the $C F P \AA$ certification trademark in the United States. In 1985 the College and CFP Board of Standards Inc. became separate entities, with the College providing education and the CFP Board of Standards supporting the CFP $\AA$ certification itself. The Board establishes and enforces the requirements for CFP candidates in terms of education, examination, experience and ethics.

Additionally, in 1985 the National Endowment for Financial Education [NEFE] was created by the College for Financial Planning as its holding company and became a private foundation in 1997. In 1986, the CFP Board adopted a Code of Ethics and Standards of Professional Conduct that outlines ethical standards for CFP ${ }^{\circledR}$ professionals as well as Disciplinary Rules and Procedures that specify the enforcement procedures for those standards. Year later, the CFP Board registered the first 25 institutions to offer financial planning education programs based on an approved curriculum.

In the early $1980 \mathrm{~s}$, the first undergraduate financial planning degree program aimed at educating professional advisers - a bachelor's degree in Financial and Estate planning - was created by Robert Bohn at Brigham Young University. In 
1982, the Golden Gate University [GGU] in San Francisco hired him to create the nation's first Masters Degree in Financial Planning and Internet Masters Degree in Finance. The second Master's program in financial planning was in the San Diego University.

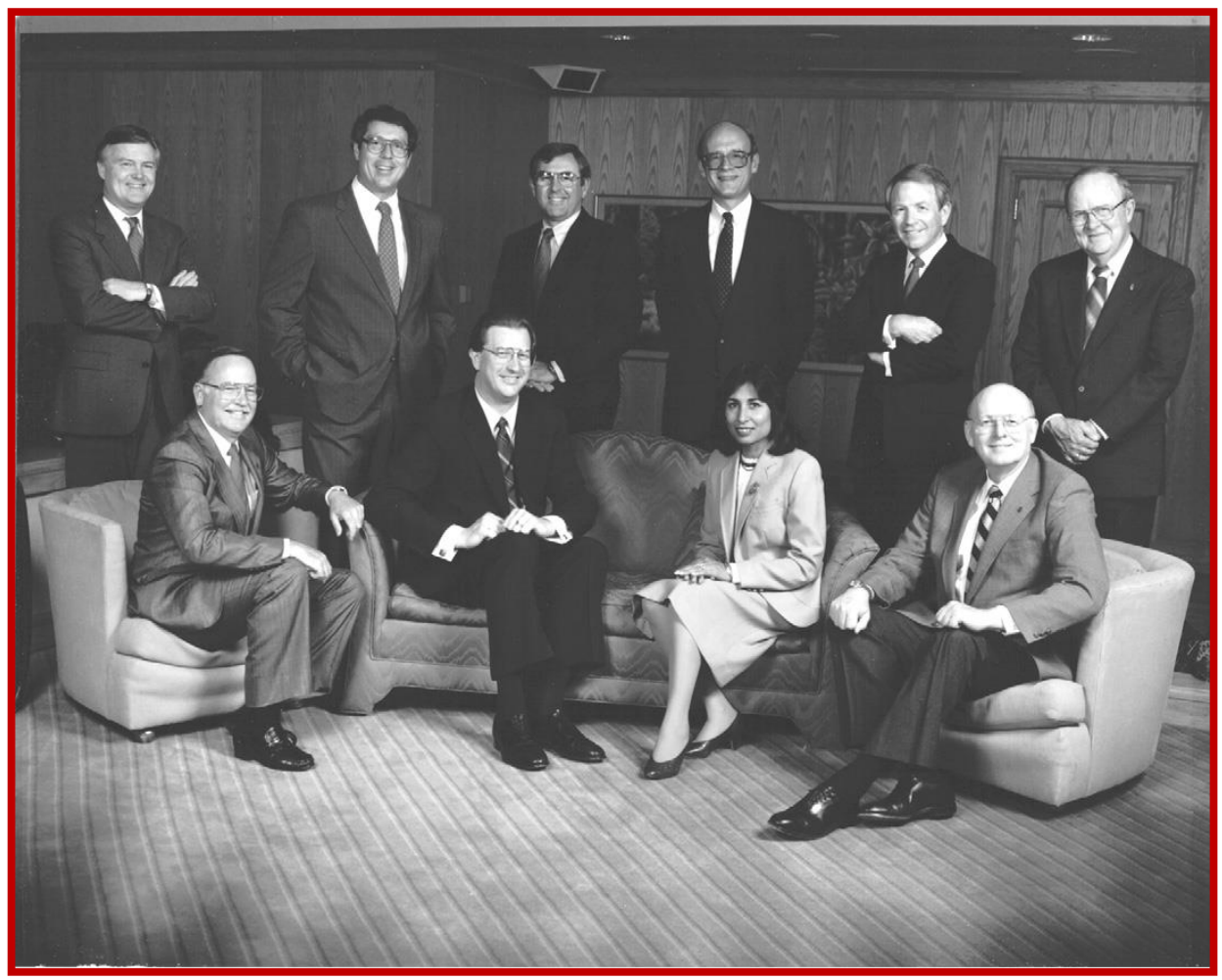

Photo 6. Original IBCFP Board, 1985-1987

Source: Financial Planning Association.

In 1986 Tax Reform Act was passed and dramatically cut tax rates and simplified tax laws. The way people planned and invested for retirement began to change. They could select investments for retirement accounts. In the same year IBCFP adopted a code of ethics and standards of practice, along with a set of disciplinary rules and procedures.

In the January 1990 issue of the Journal of Financial Planning Dick Wagner, one of the profession's greatest philosophers wrote a critique titled, 'To Think... Like a CFP', in which he assessed the state of the profession and found it wanting. Dick exhorted us to consider the true imperatives of the profession and to stop play acting, to stop complaining that we were not being taken seriously, and to 
understand that we are not self-anointed; professional status can only be bestowed by those whom we serve (Yeske, 2019). Wagner's 1990 article inspired a succession of articles that, collectively, are an essential anthology for understanding financial planning as a profession and defining what it means to be a 'financial planner.' In the July 2000 issue of the Journal of Financial Planning Elissa Buie asked: is it time for this profession to start 'To Feel...Like a CFP' in addition 'To Think...Like a CFP'? Progress had been made since Wagner challenged readers in 1990, but why was it still difficult to define financial planning and a financial planner? The answer, Buie suggested, was because the emphasis on thinking without commensurate attention being paid to feelings led to uncertainly. Almost another decade later in the April 2009 issue of The Journal of Financial Planning, Jeanne Robinson, CFP ${ }$, and Charles Hughes, CFP ${ }$, asked: what does it mean 'To Act ... Like a CFP?'. It means always putting the client's interests first (Schulaka, 2019).

In 1990, the CFP Board established the International CFP Council to promote the professionalism of financial planning services around the world and to ensure that such services are offered in an ethical and competent manner. In the same year, the IBCFP ratified an agreement that made IAFP Australia the first organization outside the United States to grant CFP certification. In 1991, the IBCFP established a subsidiary Board of Affiliated Associations which controls the licensing of CFP certificates outside the United States. The Board comprised two directors from the IBCFP and one director from each affiliated association. In 1992, the IBCFP and Japanese Association of Financial Planners signed a license and affiliation agreement. The new name for the Board of Affiliated Associations adopted in 1994 was the International CFP Council, along with a policy to promote CFP certification globally. In 1995, the CFP Board authorized the United Kingdom's Institute of Financial Planning to offer the CFP brand in that nation the first time a European financial planning organization had joined the International CFP Council. In 1994, the International Board of Standards and Practices for Certified Financial Planners was renamed the Certified Financial Planner Board of Standards and began to go by the simplified name of CFP Board. In 1995, the CFP Board began developing standards for the financial planning process. In 2008, it refined its definition to include some or all of six elements:

1) Establishing and defining the client-planner relationship.

2) Gathering client data including goals.

3) Analysing and evaluating the client's current financial status.

4) Developing and presenting financial planning recommendations and/or alternatives.

5) Implementing the recommendations.

6) Monitoring the recommendations. 
In the early 1990s, the IBCFP embarked on a revision of its Code of Ethics and Professional Responsibility (Blankinship, 1996). The natural source for the growing personal financial planning industry were insurance agents, who had to make many changes referred to as a transition -i.e. in the way they serviced clients and offered to become financial planners (Morrow, 2005a). Meanwhile, advances in technology steered financial advisors away from mainframe and time-sharing systems towards personal computers, to networked office installations, and eventually to a much heavier dependency on the Internet for program access, data sharing and communications. Now a financial advisor without a personal website is like a dentist without a reclining chair and the collection of tools suspended above it (Morrow, 2005b).

Since 1999, The Register magazine has been published by the IARFC, is a practitioner-oriented, financial magazine. The Register includes profiles, articles, interviews, book reviews, practice management techniques, product information and marketing recommendations.

In January 2000, the ICFP and the IAFP merged with more than 30,000 members and 100 chapters to form the Financial Planning Association [FPA] according to a framework approved in March 1999 after years of discussion and false starts (Cooper, 2000), which a leadership and advocacy organization based in Denver, Colorado. FPA works with academic leaders, legislative and regulatory bodies, financial services firms and consumer interest organizations. David Brand, the former executive director of the ICFP and Janet McCallen, the former executive director of the IAFP, took over as the co-CEOs of the merged organization. Brand departed at the end of 2000, leaving McCallen as the sole CEO. Additionally in the same year Texas Tech was one of the original 20 universities to create a PFP program and the first to offer a doctoral degree. In 2004, responsibility for administering the CFP certification program outside the U.S. was transferred from the CFP Board and the International CFP Council to an independent organization - the Financial Planning Standards Board Ltd. [FPSB] in Denver. FPSB Ltd. opened for business on 1 December 2004 with an affiliate network of professional financial planning bodies in 17 territories $^{3}$ and 89,690 CFP certificate holders around the world who had come together to develop, promote and enforce world-class standards for CFP certification and financial planning professionalism with a vision: to establish financial planning as a globally recognized profession, with the CFP as its symbol of excellence. At that time, there were just under 90,000 CFP professionals worldwide in 17 territories around the world committed to delivering financial planning competently and ethically in the interests of clients.

${ }^{3}$ Australia, Austria, Brazil, Canada, Chinese Taipei, France, Germany, Hong Kong, India, Japan, Malaysia, New Zealand, Republic of Korea, Singapore, South Africa, Switzerland and United Kingdom. 
In 2002 the IARFC Initiated the Journal of Personal Finance a practitioner-oriented and academic journal combined. The research based articles examine the impact of financial issues on households as well as the practice and profession of financial planning. The Journal has grown in scope, acceptance and recognition among practitioners and academicians. It welcomes articles from practicing financial professionals and consultants about financial products and services, client relationships, retirement planning, long term care, practice management, and firm operation or efficiencies.

FPA San Diego 2005 marked the beginning of the Archives for the History of Financial PlanningIn May 2005. Texas Tech University [TTU] agreed to serve as the site for the archives, which is housed in the Southwest Collections, the TTU's special collections library. This initiative, supported by the Financial Planning Association ${ }^{\circledR}\left[\right.$ FPA $\left.{ }^{\circledR}\right]$ and TTU's Personal Financial Planning Department, is responsible for acquiring and preserving items of historical significance to the financial planning profession. Through this collection, valuable historical resources will be made available onsite, electronically and through educational public outreach programs. This initiative will build on the growing collection of manuscripts, artefacts, oral histories, photographs, videos, surveys and other items assembled by E. Denby Brandon Jr., CFP®, and H. Oliver Welch, CFP®, two early CFP Board chairmen. Since 2000, Brandon and Welch have been documenting the history of the financial planning profession, supported by FPA, CFP Board, the National Endowment for Financial Education and many individuals. Ben Baldwin, a longtime close friend of Dunton's received from Loren Dunton's second wife - a Hungarian named Marta Benko Dunton, referred to by Forrest Wallace Cato as America's first lady of financial planning a collection of rare items documenting the founding of the field of financial planning, Dunton's so-called memorabilia [his books, published newsletters, awards and copies of original documents]. Baldwin decided to donate these to Texas Tech University. Marta Benko Dunton passed away in San Francisco on 22 November 2014.

In 2005, with 12 out of 16 country votes in favour, ISO 22222-2005 Personal Financial Planning. Requirements for personal financial planners was approved. These standards defined personal financial planning as a process designed to enable clients to achieve their personal financial goals and a personal financial planner was defined as individual who provides a service of personal financial planning to clients and who meets all of the ethics, competence and experience requirements contained in this international standard.

In 2007, after more than 20 years of operations in Denver, the CFP Board moved its office to Washington, DC. In the same year a bachelor's degree program to earn $C F P{ }^{\circledR}$ certification and Financial Industry Regulatory Authority [FINRA] was formulated from a consolidation of the NASD and NYSE 
Regulation. In 2008 significant revisions to the Standards of Professional Conduct took effect, including the requirement that $\mathrm{CFP}{ }^{\circledR}$ professionals providing financial planning services adhere to a fiduciary standard of care. In 2008 three organizations - the FPA, NAPFA, and CFP Board - formed the Financial Planning Coalition [FPC] to protect and educate the public in the name of financial well-being, and to influence financial services regulation. In 2009, the number of CFP professionals outside the U.S. [65,382] exceeded the number in the U.S. [60,634]. In 2011, the CFP Board launched a large-scale, national public awareness campaign to educate the public on financial planning and CFP® professionals. In 2015, the CFP Board established the Center for Financial Planning. The Center is uniquely positioned to bring firms, educators and practitioners together to leverage collective resources and address the challenges facing the profession. In 2018, the CFP Board adopted a new Code of Ethics and Standards of Conduct, effective 1 October 2019, which expands the scope of the fiduciary standards, requiring $C F P \circledR$ professionals to act in the best interest of the client at all times when providing financial advice.

It should also be pointed out that the rapid development of personal financial planning would not have been possible without popularizing and promotional activities. Among several distinguished professional editors, possibly Forrest Wallace Cato became the best-known among both financial planners nationwide and the national financial media. As Loren Dunton Cato said, 'More than any other person, [he] has written more legitimately produced or published advocacy works - for newspapers, television, magazines, wire services, books, radio, documentaries, syndicates, house organs, associations, lectures, workshop materials, training course texts, and newsletters, in 2 countries - all promoting the acceptance of planning'. These efforts included interviews essays, news releases, monograms, vide productions, speeches, open pieces, feature articles, editorials, training guides, e-mails, round-up stories, reviews, critiques biographies, and webinars. Cato helped edit, publish, promote and write the introduction to the books of Loren Dunton ['The First Words About Financial Planning', 'Your Book Of Financial Planning'] and John Keeble ['Financial Planning As I Conceived It']. Loren Dunton in his book 'Financial Planning: A New Profession,' wrote, 'Cato has a national reputation as an editor, journalist, and media promotion genius. He's written more copy to help gain acceptance, understanding, and appreciation for financial planners than any other person in America!'. Cato was the major lobbyist for financial planners and has held this position since the beginning of the planning profession. As a skilled image-builder he was wellknown for the key role he played in helping to get this new profession of financial planning respected and established soon after this specialty discipline was created.

Another distinguished writer and practicing financial advisor for financial planning was Edwin P. Morrow II. In 1969, he founded Financial Planning 
Consultants, of Middletown, Ohio, specializing in planning for corporate executives and business owners. The firm was also engaged in software development, advisor training and consulting for the financial services profession. A prolific author of over 500 articles on practice management and financial planning in professional journals, he has also published three books on practice management and designed software programs that are used by financial planners, accountants and educators. His articles, books and presentations have made him internationally renown as 'an advisor to financial advisors' for which he received the Cato Award for excellence in financial journalism and the Loren Dunton Award for his significant contributions to the financial services profession. From 1999 to 2017 he was Chairman of the IARFC.

Table 3. The Cato Award recipients

\begin{tabular}{|l|l|}
\hline 2010 William J. Nelson & \\
2009 Barry M. Ferguson & \\
2008 Christopher P. Hill & \\
2007 Wilma G. Anderson & \\
2006 Dr. Jeffrey Chiew & \\
2005 Ben G. Baldwin & \\
2004 Edwin P. Morrow II & \\
2003 John E. Grabe & \\
& \\
\hline
\end{tabular}

Source: VanderPal, 2010.

In 2003 the IARFC originated the Cato Award for Distinguished Journalism in the Field of Financial Services to formally encourage and recognize those who further general knowledge of planning by being legitimately published or receiving other positive exposure [in terms of financial planning] in the consumer, educational, financial, or news media [table 3] (VanderPal, 2010). The IARFC has discontinued the Cato award as of 2010. During a re-evaluation of the awards given, the IARFC decided to continue with the following Awards: Loren Dunton Memorial Award, Founder's Award, Ambassador Award, Member Award.

\section{PERSONAL FINANCIAL PLANNING TODAY}

There is a certain entrepreneurial aura around financial planning because it has developed organically. The competency, ethics and education requirements have been self-imposed. New ways of practicing arise from the grassroots (Schoeff, 2019b). Half a century of the development of personal financial planning and the profession of a financial planner as a professional in the financial services market 
was a time of expansion and rapid development of CFP certification both in the US and abroad worldwide accompanied by turbulent economic [including crises], regulatory, social and cultural and technological changes, as well as robo-advice. It was a time of improving the standards of providing personal financial planning services and six-step process [table 3], financial educating advisors and their clients, codifying and approving ethical standards in working with clients, and finally international standardization of the entire client work process in the preparation and implementation of personal financial plans [ISO 22222]. Since that year, when the College for Financial Planning was established, more than 330 CFP board-registered certificate and degree-granting programs were founded. While the majority of such programs grant professional certificates or undergraduate degrees, more than $45 \mathrm{MA}$ and $\mathrm{Ph} . \mathrm{D}$. level programs now exist (Chandler, 2019).

After evolving for nearly six decades since 1963, when John III Keeble drew up his first financial plan, the personal financial planning process consists of the following six steps [table 4] (Regulation and Oversight of the Financial Planning Profession, 2010):

1) Establish and define the relationship with the client.

2) Collect the client's information.

3) Analyse and assess the client's financial status.

4) Develop the financial planning recommendations and present them to the client.

5) Implement the financial planning recommendations.

6) Review the client's situation.

Table 4. Six-Steps of Personal Financial Planning

Establish and define the relationship with the client

The financial planning professional informs the client about the financial planning process, the services the financial planning professional offers, and the financial planning professional's competencies and experience. The financial planning professional and the client determine whether the services offered by the financial planning professional and his or her competencies meet the needs of the client. The financial planning professional considers his or her skills, knowledge and experience in providing the services requested or likely to be required by the client. The financial planning professional determines if he or she has, and discloses, any conflict[s] of interest. The financial planning professional and the client agree on the services to be provided. The financial planning professional describes, in writing, the scope of the engagement before any financial planning is provided, including details about: the responsibilities of each party [including third parties]; the terms of the engagement; and compensation and conflict[s] of interest of the financial planning professional.

The scope of the engagement is set out in writing in a formal document signed by both parties or formally accepted by the client and includes a process for terminating the engagement. 


\section{Collect the client's information}

The financial planning professional and the client identify the client's personal and financial objectives, needs and priorities that are relevant to the scope of the engagement before making and/or implementing any recommendations. The financial planning professional collects sufficient quantitative and qualitative information and documents about the client relevant to the scope of the engagement before making and/or implementing any recommendations.

Analyze and assess the client's financial status

The financial planning professional analyses the client's information, subject to the scope of the engagement, to gain an understanding of the client's financial situation. The financial planning professional assesses the strengths and weaknesses of the client's current financial situation and compares them to the client's objectives, needs and priorities.

Develop the financial planning recommendations and present them to the client

The financial planning professional considers one or more strategies relevant to the client's current situation that could reasonably meet the client's objectives, needs and priorities; develops the financial planning recommendations based on the selected strategies to reasonably meet the client's confirmed objectives, needs and priorities; and presents the financial planning recommendations and the supporting rationale in a way that allows the client to make an informed decision.

Implement the financial planning recommendations

The financial planning professional and the client agree on implementation responsibilities that are consistent with the scope of the engagement, the client's acceptance of the financial planning recommendations, and the financial planning professional's ability to implement the financial planning recommendations. Based on the scope of the engagement, the financial planning professional identifies and presents appropriate product[s] and service[s] that are consistent with the financial planning recommendations accepted by the client.

Review the client's situation

The financial planning professional and client mutually define and agree on terms for reviewing and reevaluating the client's situation, including goals, risk profile, lifestyle and other relevant changes. If conducting a review, the financial planning professional and the client review the client's situation to assess progress toward achievement of the objectives of the financial planning recommendations, determine if the recommendations are still appropriate, and confirm any revisions mutually considered necessary.

Source: based on FPSB.

Personal financial planning $[\mathrm{PFP}]$ is now a process that literally incorporates all items of financial interest to an individual. The most common areas and its aims are (Lewis, 2004):

1) tax planning - minimizing taxes,

2) cash flow planning - savings and spending policies, 
3) investments - efficient deployment of resources for the future,

4) risk management - incorporation of insurance and other practices to establish and limit household exposures to uncertainty

5) retirement planning - life cycle planning for the period in which workrelated income ceases

6) estate planning - organizing finances with concern for other household members and other people and causes, most typically, for the period beyond the demise of the asset holder.

At the end of 2019 CFP certification is available in 26 countries around the world, and CFP certification at the end of 2019 was held by 188,104 people, including 86,378 holders in the USA 101,726 holders outside the USA [table 5]. According to the FPSB strategic plans, by 2025 , CFP certification will be available in 40 countries around the world with 250,000 holders

Table 5. FPSB Member Organizations and CFP holders at the end of 2019

\begin{tabular}{|c|c|c|c|}
\hline Area & Member Organization & $\begin{array}{l}\text { Year of Offering CFP } \\
\text { Certification }\end{array}$ & $\begin{array}{l}\text { CFP Holders } \\
\text { [end of 2019] }\end{array}$ \\
\hline AUSTRALIA & $\begin{array}{c}\text { Financial Planning } \\
\text { Association of Australia, } \\
\text { Ltd. }\end{array}$ & 1990 & 5523 \\
\hline AUSTRIA & $\begin{array}{l}\text { Österreichischer Verband } \\
\text { Financial Planners }\end{array}$ & 2002 & 333 \\
\hline BRAZIL & $\begin{array}{l}\text { Instituto Brasileiro de } \\
\text { Certificação de } \\
\text { Profissionais Financeiros }\end{array}$ & 2002 & 4674 \\
\hline CANADA & $\begin{array}{l}\text { Financial Planning } \\
\text { Standards Council }\end{array}$ & 1996 & 16435 \\
\hline $\begin{array}{l}\text { PEOPLE'S } \\
\text { REPUBLIC OF } \\
\text { CHINA }\end{array}$ & $\begin{array}{c}\text { Financial Planning } \\
\text { Standards Board China, } \\
\text { Ltd. }\end{array}$ & 2006 & 22048 \\
\hline CHINESE TAIPEI & $\begin{array}{l}\text { Financial Planning } \\
\text { Association of Taiwan }\end{array}$ & 2004 & 1836 \\
\hline COLOMBIA & $\begin{array}{l}\text { Asociación Colombiana de } \\
\text { Planeación Financiera }\end{array}$ & 2014 & 10 \\
\hline FRANCE & $\begin{array}{l}\text { Association Française des } \\
\text { Conseils en Gestion de } \\
\text { Patrimoine Certifies }\end{array}$ & 1997 & 1358 \\
\hline
\end{tabular}




\begin{tabular}{|c|c|c|c|}
\hline GERMANY & $\begin{array}{l}\text { Financial Planning } \\
\text { Standards Board } \\
\text { Deutschland }\end{array}$ & 1997 & 1514 \\
\hline HONG KONG & $\begin{array}{c}\text { Institute of Financial } \\
\text { Planners of Hong Kong Ltd. }\end{array}$ & 2000 & 4377 \\
\hline INDIA & $\begin{array}{c}\text { Financial Planning } \\
\text { Standards Board India }\end{array}$ & 2001 & 1915 \\
\hline INDONESIA & $\begin{array}{c}\text { Financial Planning } \\
\text { Standards Board Indonesia }\end{array}$ & 2006 & 1932 \\
\hline IRELAND & $\begin{array}{c}\text { Financial Planning } \\
\text { Standards Board Ireland }\end{array}$ & 2008 & 710 \\
\hline ISRAEL & $\begin{array}{l}\text { Union of Financial Planners } \\
\text { in Israel Associate Member }\end{array}$ & 2011 & 187 \\
\hline JAPAN & $\begin{array}{l}\text { Japan Association for } \\
\text { Financial Planner }\end{array}$ & 1992 & 22254 \\
\hline MALAYSIA & $\begin{array}{c}\text { Financial Planning } \\
\text { Association of Malaysia }\end{array}$ & 2000 & 2181 \\
\hline $\begin{array}{c}\text { THE } \\
\text { NETHERLANDS }\end{array}$ & $\begin{array}{c}\text { Financial Planning } \\
\text { Standards Board Nederland }\end{array}$ & 2009 & 3099 \\
\hline NEW ZEALAND & $\begin{array}{l}\text { Institute of Financial } \\
\text { Advisers }\end{array}$ & 1996 & 239 \\
\hline $\begin{array}{l}\text { REPUBLIC OF } \\
\text { KOREA }\end{array}$ & $\begin{array}{c}\text { Financial Planning } \\
\text { Standards Board Korea }\end{array}$ & 2000 & 3868 \\
\hline SINGAPORE & $\begin{array}{c}\text { Financial Planning } \\
\text { Association of Singapore }\end{array}$ & 1998 & 1033 \\
\hline SOUTH AFRICA & $\begin{array}{c}\text { Financial Planning Institute } \\
\text { of Southern Africa }\end{array}$ & 1998 & 4686 \\
\hline SWITZERLAND & $\begin{array}{l}\text { Swiss Financial Planners } \\
\text { Organization }\end{array}$ & 1999 & 295 \\
\hline THAILAND & $\begin{array}{c}\text { Thai Financial Planners } \\
\text { Association }\end{array}$ & 2009 & 322 \\
\hline $\begin{array}{l}\text { UNITED } \\
\text { KINGDOM }\end{array}$ & $\begin{array}{l}\text { Institute of Financial } \\
\text { Planning Ltd. }\end{array}$ & 1995 & 897 \\
\hline UNITED STATES & CFP Board & 1972 & 86378 \\
\hline \multicolumn{3}{|c|}{ TOTAL } & 188104 \\
\hline
\end{tabular}

Source: based on FPSB. 
In Europe, apart from the indicated FPSB branches, in selected countries there were 2 organizations dealing with standardization, education and certification of financial advisers - the European Federation of Financial Professionals [EFFP] in Bad Homburg [Germany] and the European Financial Planning Association [EFPA] in Rotterdam [the Netherlands]. The European Federation of Financial Advisers and Financial Intermediaries [FECIF] with its seat in Brussels has been operating since 1999, in which EFFP Europe and EFPA Europe are affiliated.

\section{CONCLUSION}

The 50th anniversary of the financial and personal financial planning profession and financial advisor can be a good opportunity to summarize their achievements. Financial planning is a holistic, client-centred approach, focused on satisfying the financial needs of households throughout its life cycle. It allows better control of daily expenses and saving for a specific purpose, such as children's education, or larger expenses like housing or raising retirement capital. Financial planning helps in the financial management of everyday life [nanofinance], which increases the parameters of household financial security. Half a century has passed since the memorable two-day meeting organized by Loren Dunton in December 1969, and the activities and profession proposed by the participants of the meeting are now available globally and considered one of the most important credentials in personal financial advice. Financial consulting has a very large growth potential, especially in countries where it is currently less developed, e.g. in Poland. The factors that will dynamize the demand for professional financial advisory services will be the increase in the wealth of the society, the increase in financial awareness, the inefficiency of pension systems and the increased complexity of instruments on the financial markets.

\section{REFERENCES}

Baldwin, Ben G. (2000). You should know... Loren Dunton. Advisor Today, Jun, 95, p. 16.

Blankinship, John T., Jr. Milestones and challenges for the financial planning profession. Journal of Financial Planning, Dec 1996, pp. 97-98.

Brendon, D. and Welch, O. (2009). The History of Financial Planning The Transformation of Financial Services, NJ: John Wiley \& Sons.

Cato, F.W. (2002a). VIP interview with industry leader John B. Keeble. III, Financial Services Advisor, Jul/Aug, pp. 16-23.

Cato, F.W. (2002b). The Cato connection. Financial Services Advisor, May/Jun, pp. 35-37.

Chandler, S. (2019). The Best Schools for Financial Planning. 16 May 2019, https://www.investopedia.com/articles/financial-advisors/012215/best-schools-financial-planning.asp [Accessed 12.12.2020]. 
Cooper, J. (2000). New financial planning association begins! Financial Services Advisor, Jan/Feb, pp. 52-55.

Dunton, L. (1986). The financial planner: A new professional... yesterday - today - tomorrow, Chicago, IL: Longman Financial Services Pub.

FPA, https://www.financialplanningassociation.org/lead/awards-scholarships/p-kemp-fain-jraward [Accessed 28.03.2021].

FPSB, https://www.fpsb.org/ [Accessed 31.12.2020].

Grable, J.E., Archuleta, K.L., Roudi, R. and Roy, N. (2011). Financial Planning and Counseling Scales, NY: Springer.

IARFC, https://www.iarfc.org/events/awards [Accessed 28.03.2021].

Keeble, J.B, III (2003). Perspectives on your future: The American dream. Financial Services Advisor, May/June, pp. 33-35.

Lewis, A. (2004). Personal Financial Planning: Origins, Developments and a Plan for Future Direction. The American Economist, 4, pp. 53-60, doi.org/10.1177/056943450404800204

Morrow, Edwin P. (2000). Financially speaking by Loren Dunton. Advisor Today, Jul, pp. 16-17.

Morrow, Edwin P. (2002a). John Keeble: Wisdom from a true pioneer financial advisor. Financial Services Advisor, Mar/Apr, pp. 16-17.

Morrow, Edwin P. (2002b). The origin of financial planning professionals. Financial Services Advisor, Mar/Apr, pp. 18-21.

Morrow, Edwin P. (2005a). Making the transition from agent to advisor. Journal of Personal Finance, 4(1), pp. 98-109.

Morrow, Edwin P., (2005b). Professional trends what's happening in financial services? Journal of Personal Finance, 4(2), pp. 22-26.

Origins of Our Profession, (2008). The Register, September, pp. 5-9.

Peck, M. (2009). Celebrating the Birth of a Profession. Journal of Financial Planning, supl. FPA ANAHEIM, pp. 6-7.

Regulation and Oversight of the Financial Planning Profession, (2010). Financial Planning Standards Board Ltd. [FPSB], 10/2010, https://www.fpsb.org/wp-content/uploads/2010/01/Oversight-of-the-Financial-Planning-Profession-Oct-2010_LR.pdf [Accessed 13.12.2020].

Ritchlin, L. (2009a). Financial Planning Pioneer Lewis G. Kearns on the 40th Anniversary of the Profession. Journal of Financial Planning, December, pp. 14-16.

Ritchlin, L. (2009b). Founders of the Profession Look Back on the Roots of Financial Planning. Journal of Financial Planning, October, pp. 32-34.

Schoeff, M. Jr. (2019a). Financial planning founders started a movement - and created a profession, Investment News, September 14, https://www.investmentnews.com/financial-planning-founders-started-a-movement-and-created-a-profession-81110 [Accessed 01.03.2021].

Schoeff, M. Jr. (2019b). 50th Anniversary of Financial Planning. Investment News, 9/16, p. 10.

Schulaka, C. (2019). To Think, Feel, Act, and Learn Like a CFP. Journal of Financial Planning, February, p. 12.

Tuttle, Marv. (1996). A new phase. Journal of Financial Planning, February, p. 8.

VanderPal G. (2010). The Cato Award Benefits You. The Register, January, pp. 4-7.

Walker, L. (2018). The Profession of Financial Planning: Past, Present, and the Next 45 Years. Journal of Financial Planning, Mar, Vol.31(3), pp. 20-26.

Yeske, D. (2016). A Concise History of the Financial Planning Profession. Journal of Financial Planning, September, pp. 10-13.

Yeske, D. (2019). Happy 50th Anniversary, Financial Planning Profession, Journal of Financial Planning, October, pp. 18-20. 